\title{
PERANCANGAN APLIKASI PENDAFTARAN PASIEN PADA UPTD PUSKESMAS \\ BUMI EMAS LAMPUNG TIMUR
}

\author{
Vico Firmansyah ${ }^{(1)}$ Dedi Irawan ${ }^{(2)}$ \\ Jurusan Ilmu Komputer, Fakultas Ilmu Komputer,Universitas Muhammadiyah Metro \\ Jl.Gatot Subroto No.100 Yosodadi Kota Metro, Telpon :(0725)42445-Fax(0725)42454 \\ E-mail: dedi.mti@gmail.com
}

\begin{abstract}
Abstrak
Kondisi saat ini pada UPTD puskesmas bumiemas dalam pengolahan data pasien pendaftaran masih menggunakan metode pembukuan (buku besar), maka dalam pengolahan data masih banyak mengalami kendala yaitu, a) belum adanya aplikasi pendaftaran yang mempermudah dalam penginputan data pasien yang berobat di UPTD puskesmas bumiemas, b) dalam pembuatan laporan buku besar register kunjungan pasien yang di tunjukan untuk Kepala Puskesmas kurang efektif dan efisien. Pendaftaran pasien akan berjalan dengan baik apabila sistem teknologi yang digunakan sudah secara komputerisasi, maka sangat memungkinkan untuk melakukan pendataan dan pengolahan lebih cepat. UPTD puskesmas bumiemas adalah lembaga kesehatan yang yang menyelenggarakan upaya kesehatan yang bersifat menyeluruh, terpadu, merata, dapat ditrima dan terjangkau oleh masyarakat dengan peran serta aktif masyarakat dan menggunakan hasil pengembangan ilmu pengetahuan dan teknologi tepat guna, dengan biaya yang dapat dipikul oleh pemerintah dan masyarakat luas guna mencapai derajat kesehatan yang optimal. Dalam perancangan aplikasi pendaftaran pasien ini penulis menggunakan 2 metode, yang pertama yaitu studi lapangan yang terdiri dari observasi, wawancara, dan dokumentasi. Sedangkan metode yang kedua yaitu studi putaka. Selain itu dalam perkembangan aplikasi penulis menggunakan aliran informasi, diagram conteks, data flow diagram, dan entitiy relationship diagram.sofware pendukung dalam pembuatan aplikasi ini adalah Delphi 7.0, database MYSQL dan Quick riport. Perancangan aplikasi pendaftaran pasien pada UPTD puskesmas bumiemas lampung timur menghasilkan rancangan input data pasien, data kunjungan pasien, serta outputnya berupa laporan data kunjungan pasien.
\end{abstract}

Kata Kunci: Perancangan Aplikasi Pendaftaran Pasien Pada UPTD Puskesmas Bumiemas Lampung Timur, Delphi 7.0, Database MYSQL, Quick Riport.

\section{PENDAHULUAN}

Pada era globalisasi seperti sekarang ini teknologi sudah semakin maju. Hal ini dapat kita lihat begitu mudahnya masyarakat mendapatkan suatu informasi secara cepat, tepat, dan akurat. Kemajuan teknologi ini juga memicu suatu organisasi atau lembaga kesehatan untuk menggunakan teknologi berbasis komputer atau jaringan, untuk mempermudah suatu pekerjaan agar lebih cepat, tepat, dan akurat. Perkembangan teknologi juga dapat mempengaruhi proses pendaftaran pasien pada suatu lembaga 
kesehatan, atau UPTD Puskesmas, proses pemdaftaran pasien menjadi cerminan kualitas dari UPTD Puskesmas tersebut. Dengan pelayanan yang baik akan memberikan kenyamanan pada pasien yang berobat. UPTD Puskesmas Bumiemas merupakan salah satu Lembaga Kesehatan yang ada di kabupaten Lampung Timur. Dalam Undang-undang no 36 Tahun 2009 tentang kesehatan. Musyawarah daerah menyerahkan pada pengurus untuk mendirikan UPTD Puskesmas Bumiemas sebagai sarana dalam meningkatkan mutu pelayanan kesehatan dasar. Dari berbagai study kelayakan dan beberapa analisis selama beberapa bulan. UPTD Puskesmas Bumiemas mulai di bangun pada tanggal 0102-2011. SK pendirian Lembaga 239/10/SK/2012 yang dipimpin oleh dr. Desna Damayanti. Yang Beralamatkan di Desa Bumiemas, Bedeng 42 Kec. Batanghari Kab. Lampung Timur. Nabi Muhammad SAW bersabda kesehatan merupakan hak bagi tubuh manusia karna kesehatan merupakan hak manusia. Ada banyak sekali dalil-dalil dalam kitab suci AlQuran yang menjelaskan tentang pentingnya menjaga kesehatan, Seperti firman Allah pada QS Yunus ayat 57:

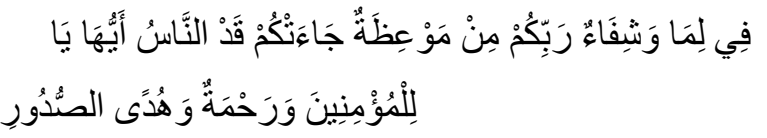

Artinya: "Hai manusia, Sesungguhnya telah datang kepadamu pelajaran dari tuhanmu dan penyembuh bagi penyakit-penyakit (yang berada) dalam dada dan petunjuk serta rahmat bagi orang-orang yang beriman”. (QS Yunus ayat 57)

Kondisi saat ini pada UPTD Puskesmas Bumiemas dalam pengolahan data pasien pendaftaran masih menggunakan metode pembukuan (buku besar), maka dalam pengolahan data masih banyak mengalami kendala yaitu, a) belum adanya aplikasi pendaftaran yang mempermudah dalam penginputan data pasien yang berobat di UPTD Puskesmas Bumiemas, b) dalam pembuatan laporan buku besar register kunjungan pasien yang di tunjukan untuk Kepala Puskesmas kurang efektif dan efisien. Pendaftaran pasien akan berjalan dengan baik apabila sistem teknologi yang digunakan sudah secara komputerisasi, maka sangat memungkinkan untuk melakukan pendataan dan pengolahan lebih cepat. Berdasarkan latar belakang permasalahan yang telah tercantumkan di atas, maka dalam penyusunan tugas akhir ini penulis mengambil judul yang berkaitan yaitu:"PERANCANGAN APLIKASI PENDAFTARAN PASIEN PADA UPTD PUSKESMAS BUMIEMAS LAMPUNG TIMUR" 


\section{KAJIAN PUSTAKA DAN LANDASAN TEORI}

\subsection{Definisi Perancangan}

Menurut Soetam Rizky yang dikutipoleh AdiSaputra, Mulyadi, danMartono (2014:129) mendefinisikan"perancangan adalah sebuah proses untuk mendefenisikan suatu yang akan dikerjakan dengan mengunakan teknik yang bervariasi serta didalam melibatkan deskripsi mengenai arsitektur serta detail komponen dan juga keterbatasan yang akan dialami dalam proses pengerjaanya". Menurut Eddy Prahasta yang dikutipolehAdiSaputra, Mulyadi, danMartono (2014:129) mendefinisikan "perancangan adalah suatu proses pengunaan berbagai prinsip dan teknik untuk tujuan - tujuan pendefenisian suatu perangkat, proses, atau sistem hingga ketingkat detail tertentu yang memungkinkan realisasi (implementasi) bentuk fisiknya (termasuk aplikasi perangkat lunak)".

\subsection{Definisi Aplikasi}

Menurut Febrian yang dikutip oleh Susanto (2014:55) Mendefinisikan "aplikasi adalah program siap pakai, program yang direka untuk melaksanakan suatu fungsi bagi pengguna atau aplikasi lain. Menurut Purnomo dalam Harahap yang dikutip oleh Susanto (2014:56) Mendefinisikan "aplikasi adalah sebuah kegiatan pengolahan data suatu urusan tertentu dari sebuah perusahaan".

\subsection{Definisi Pendaftaran}

Menurut Kamus Besar Bahasa Indonesia yang dikutip oleh Susanto (2014:56) Mendefinisikan "Pendaftaran adalah proses, cara, pembuatan mendaftar (mendaftarkan); pencatatan nama, alamat dan lain sebagainya".

\subsection{DefinisiPasien}

Menurut Kamus Besar Bahasa Indonesia yang dikutip oleh Reni Agustiani(2007:39) Mendefinisikan"Pasien adalah orang yang sakit yang berada dibawah perawatan seorang dokter, penderita penyakit yang berobat ditempat praktek dokter, bidan, rumah sakit, klinik".

\subsection{Definisi Puskesmas}

Depkes RI yang dikutip oleh Nor Sanah (2017:307) Mendefinisikan "Puskesmas adalah unit pelaksana teknis Dinas Kesehatan Kabupaten/Kota yang bertanggung jawab menyelenggarakan pembangunan kesehatan di suatuwilayah kesehatan". Menurut IlhamAkhsanu Ridhoyang dikutip oleh Nor Sanah (2017:307) Mendefinisikan "Puskesmas adalah suatu unit organisasi yang bergerak dalam bidang pelayanan kesehatan yang berada di garda terdepan dan mempunya imisi sebagai pusat pengembangan pelayanan kesehatan, yang melaksanakan pembinaan dan pelayanan kesehatan secara menyeluruh dan terpadu untuk masyarakat di suatu wilayah kerja tertentu yang telah ditentukan secara mandiri dalam menentukan kegiatan pelayanan namun tidak mencaku paspek pembiayaan". Pemrograman Borland Delphi 7

Borland Delphi merupakan suatu bahasa pemrograman yang memberikan berbagai fasilitas pembuatan aplikasi visual. Keunggulan bahasa pemrograman ini terletak pada produktifitas, kualitas, dan pengembangan perangkat lunak, kecepatan kompilasi pada desain yang menarik, serta diperkuat dengan pemorograman yang terstruktur. Keunggulan lain dari Delphi adalah dapat membangun berbagai aplikasi Windows (permainan, multimedia, database dan lain-lain) dengan cepat dan mudah. Vm Pada tanggal 8, borland mengumumkan akan melepas seluruh jajaran produk pengenmbangan aplikasi komputernya 
termasuk di antaranya delphi. Kemudian pada bulan november 2006, jajaran produk tersebut dipisah menjadi perusahaan CodeGear. Sejak diakusisi pada bulan juli 2008. Delphi menjadi bagian dari jajaran IDE milik Embarcadero Technologies perusahaan ini megakuisisi CodeGear. Pada tahun 1996, Chief Archhitect yang membidani Delphi (juga pendahulunya Turbo Padcal) meninggalkan borland untuk pindah ke microsoft dan menjadi Chief Designer C\# serta termasuk tokoh kunci dalam perancangan Microsoft ,Net Framework. Delphi 8 (dirilis pada bulan desember 2003) dengan penampilan user interface (look and feel) mirip dengan Microsoft Visual Studio .NET. Delphi versi 8 hasil menghasilkan kode untukNET saja, sedangkan untuk pengembangan aplikasi Win32, dalam package Delphi 8 disertakan Delphi 7. Tapi menurut penulis, Delphi versi 8 gagal total.

\subsection{Komponen-Komponen Borland Delphi 7 \\ Toolbar}

Delphi memiliki beberapa toolbar yang masing-masing yang memiliki perbedaan fungsi dan setiap tombol pada bagian toolbar berfungsi sebagai pengganti suatu menu perintah yang sering digunakan.

\section{Component Pallete}

Component pallete berisi kumpulan ikon yang melambangkan komponen-komponen yang terdapat pada VCL (Visual Compenent Library).

Adapun tombol-tombol yang terdapat pada Component palette adalah seperti pada tabel

2.1.dibawah ini:

Tabel 2.1Komponen-komponenToolbar

\begin{tabular}{|l|l|}
\hline Komponen & Fungsi \\
\hline Pointer & $\begin{array}{l}\text { Pointer adalahkomponenkhususdan terdapat di } \\
\text { setiap tab dalam component palette. Komponen } \\
\text { pointer adalah komponen select yang digunakan } \\
\text { untuk memilih komponen-komponen dalam form } \\
\text { designer. }\end{array}$ \\
\hline Frames & $\begin{array}{l}\text { Frames adalahsebuahcontaineryang digunakan } \\
\text { untuk menampung komponen. Frame }\end{array}$ \\
\hline
\end{tabular}

\begin{tabular}{|c|c|}
\hline Komponen & $\begin{array}{l}\text { dapatdiletakkandalamform atauframe-frame yang } \\
\text { lain. } \\
\text { Fungsi }\end{array}$ \\
\hline $\begin{array}{c}\text { MainMenu } \\
\text { 믐- }\end{array}$ & $\begin{array}{l}\text { MainMenu adalah komponen yang digunakan untuk } \\
\text { membuat menu bar dan menu drop }\end{array}$ \\
\hline Label & $\begin{array}{l}\text { Labeladalah komponen hanya digunakan } \\
\text { untukmenambahkan teks dalam form. }\end{array}$ \\
\hline Edit & $\begin{array}{l}\text { Edit adalah komponen yang digunakan untuk } \\
\text { menerima satu baris teks yang merupakan data input } \\
\text { pemakai. Komponen ini juga dapat digunakan untuk } \\
\text { menampilkan teks. }\end{array}$ \\
\hline $\begin{array}{c}\text { Memo } \\
\overline{\underline{-}} \\
\end{array}$ & $\begin{array}{l}\text { Memo adalah komponen yang digunakan untuk } \\
\text { memasukkan atau menampilkan beberapa baris teks } \\
\text { didalam form. }\end{array}$ \\
\hline Button & $\begin{array}{l}\text { Button adalah komponen yang dipakai untuk } \\
\text { membuat button yang dipakai untuk membuat } \\
\text { button yang akan dipakai untuk memilih pilihan di } \\
\text { dalam aplikasi. Jika anda mengklik komponen } \\
\text { button tersebut maka suatu perintah atau kejadian } \\
\text { akan dijalankan. }\end{array}$ \\
\hline
\end{tabular}

\section{METODE}

Metode pengumpulan data adalah kesatuan metode- metode, prosedur, konsep-konsep dalam memperoleh data guna menyusun Tugas Akhir. Penulis menggunakan metode - metode yaitu sebagai berikut:

\section{Studi Lapangan}

Untuk mendapatkan data, penulis melakukan studi lapangan dengan menggunakan teknik:

\section{- Pengamatan (Observasi)}

Yaitu metode pengumpulan data dengan cara melakukan pengamatan secara langsung sistem yang sedang berjalan di UPTD Puskesmas Bumiemas.

\section{- Wawancara (Interview)}


Yaitu metode pengumpulan data dengan cara melakukan komunikasi dan tanya jawab secara langsung dengan "Ibu Siti Towiyah, Amd.Kep” sebagai Staf di bagian Pendaftaran.

\section{- Dokumentasi (Dokumentation)}

Dokumentasi adalah metode pengumpulan data dengan cara mengumpulkan dokumen arsip yang dibutuhkan untuk penelitian.

\section{Studi Pustaka}

Yaitu dengan cara mengumpulkan data dengan membaca buku dan mempelajari literatur yang berkaitan dengan masalah yang dihadapi.

\section{PEMBAHASAN}

\subsection{Hasil Penelitian}

Adapun hasil penelitian yang penulis dapatkan dari hasil KKP (Kuliah Kerja Praktek) yang dilakukan diUPTD Puskesmas BumiemasLampung Timur pada 03 maret - 05 mei pada bagian Pendaftaran, dan melakukan wawancara dengan penanggung jawab bagian Pendaftaran, maka penulis menemukan masalahpada UPTD Puskesmas Bumiemas dalam pengolahan data pasien pendaftaran masih menggunakan metode pembukuan (buku besar), maka dalam pengolahan data masih banyak mengalami kendala yaitu, a) belum adanya aplikasi pendaftaran yang mempermudah dalam penginputan data pasien yang berobat di UPTD Puskesmas Bumiemas, b) dalam pembuatan laporan buku besar register kunjungan yang di tunjukan untuk Kepala Puskesmas kurang efektif dan efisien. Pendaftaran pasien akan berjalan dengan baik apabila sistem teknologi yang digunakan sudah secara komputerisasi, maka sangat memungkinkan untuk melakukan pendataan dan pengolahan lebih cepat. Dari masalah tersebut maka penulis merancang kebutuhan-kebutuhan yang diperlukan dalam pembuatan aplikasi Pendaftaran Pasienyang akan dijelaskan pada sub berikutnya.

\section{A. Kebutuhan Sumber Daya}

\section{Perangkat keras (Hardware)}

Rancangan perangkat keras (hardware) yang diusulkan untuk dipergunakan dalam perancangan sistem yang dirancang adalah:

a. 1 unit laptop tipe: ASUS

b. Processor Intel core 2celeron

c. Memory (RAM) $2 \mathrm{~GB}$

d. Hardisk $500 \mathrm{~GB}$

e. 1 unit printer

\section{Perangkat lunak (Software)}

Pada rancangan ini penulis menggunakan beberapa perangkat lunak untuk mendukung 
dalam perancangan aplikasi pendaftaran pasien. Berikut ini adalah perangkat lunak yang diperlukan:

a. Sistem operasi Microsoft windows 7.

b. Sistem tipe : 64-bit / 32-bitOperating System

c. Borland Delphi 7

d. Web server : xampp (MySQL)

e. Browser : Google chrome

f. Cetak laporan : Quick report

\section{Perangkat pikir (Brainware)}

Untuk dapat melaksanakan sistem yang dirancang yaitu Perancangan Aplikasi Pendaftaran Pasien pada UPTD Puskesmas Bumiemas Lampung Timur yang sudah dirancang, diperlukan seorang operator yaitu adminyang bertugas untuk mengolah Aplikasi Pendaftaran pasien dan dapat mengakses semua bagian dari aplikasi.

\section{B. Hasil Rancangan Sistem}

Tahapan hasil rancangan sistem merupakan proses penerapan perancangan prosedurprosedur dan metode baru agar sistem yang dirancang diharapkan dapat berjalan sesuai dengan yang direncanakan. Perumusan rancangan yang penulis usulkan adalah Perancangan aplikasi Pendaftaran Pasien pada UPTD puskesmas bumiemas Lampung Timur dilakukan secara komputerisasi. Pendaftaran pasien yang sedang berjalan pada saat ini belum memanfaatkan computeryang ada. Oleh karena itu sistem yang penulis rancang dituangkan dalam bentuk aplikasi menggunakan software Borland Delphi 7 yang memiliki kelebihan yaitu penggunaan sistem yang mudah dalam pengoperasianya.

\section{Rancangan Aliran Informasi Yang Diusulkan}

Pertama jika pasien baru yang berobat maka harus menyiapkan, KTP dan KK, setelah itu identitas pasien diberikan kebagian pendaftaran, kemudian staf pendaftaran menginput data pendaftaran pasien di aplikasi pendaftaran, kemudian staf membuatkan kartu register pendaftaran. Untuk pasien lama pertama menyiapkan kartu register pendaftaran, setelah itu kartu register pendaftaran diberikan kebagian pendaftaran, kemudian staf pendaftaran menginput data kunjungan pasien, Selanjutnya staf pendaftaran membuatan laporan buku besar register kunjungan. kemudian laporan di cetak dan diberikan kepada kepala puskesmas, kemudian kepala puskesmas menandatangani laporan buku besar register pendaftaran.

\section{Rancangan Diagram Konteks}


Diagram konteks merupakan penggambaran suatu lingkaran besar yang dapat mewakili seluruh proses yang terdapat didalam suatu sistem. Adapun diagram konteks Pendaftaran Pasien yang diusulkan dapat dilihat pada gambar 4.1 berikut ini:

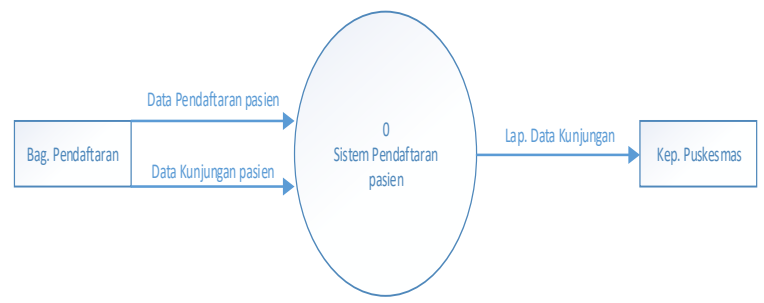

Gambar 4.1. Tampilan diagram konteks Pendaftaran Pasien

\section{Rancangan Data Flow Diagram (DFD)}

Data Flow Diagram adalah suatu proses untuk menggambarkan dari mana asal data, dan kemana tujuan data yang keluar dari sistem, dimana data akan disimpan, dan proses untuk menghasilkan data. Adapun gambar DFD pendaftaran pasien yang diusulkan dapat dilihat pada gambar 4.2 berikut ini:

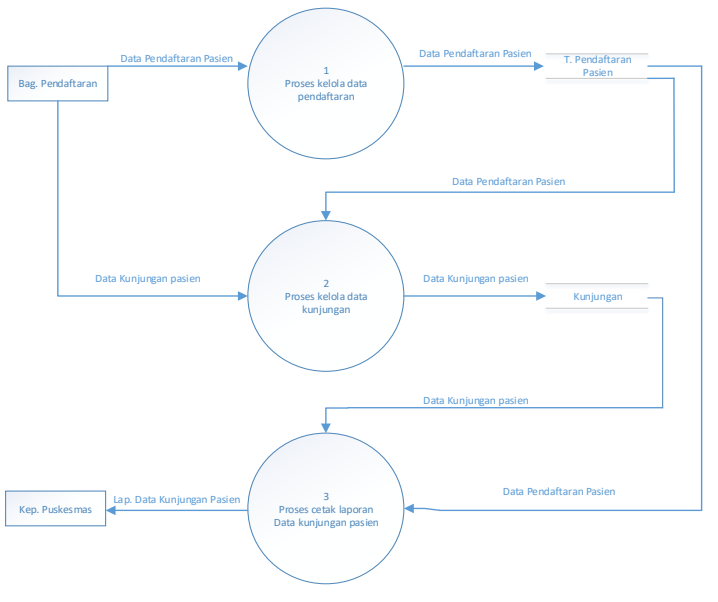

Gambar 4.2. DFD Sistem Pendaftaran Pasien

\section{Rancangan Entity Relationship Diagram (ERD)}

ERD merupakan teknik yang digunakan untuk memodelkan kebutuhan data dari suatu organisasi biasanya oleh sistem analisis dalam tahap analisis persyaratan proyek pengembangan sistem. Adapun gambar ERD dari sistem yang diusulkan dapat dilihat pada gambar 4.3 berikut ini:

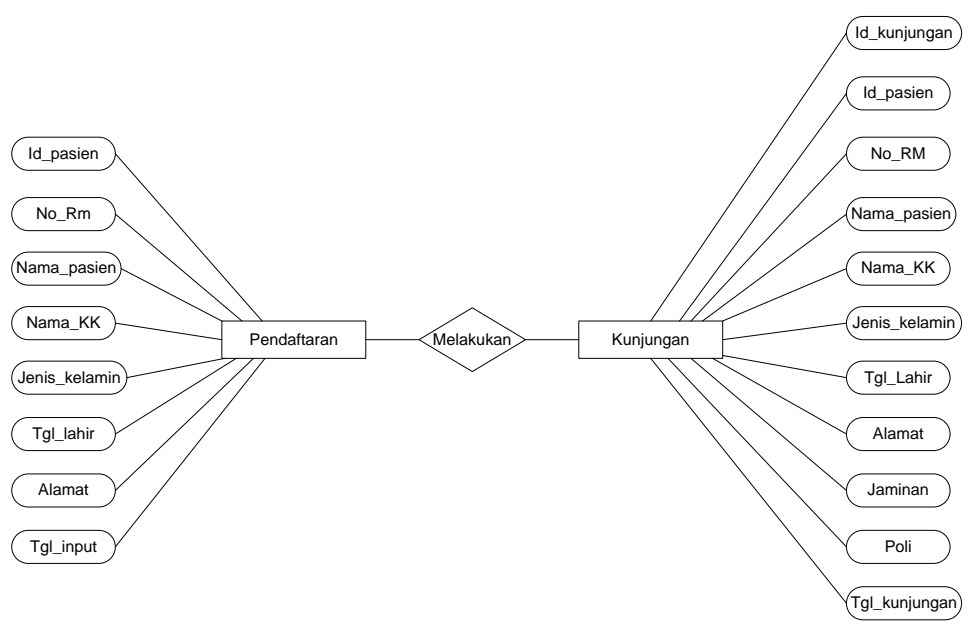


Gambar 4.3. ERD Pendaftaran Pasien

\section{Rancangan Diagram alir (Flowchart)}

Diagram alir atau flowchart merupakan sebuah diagram dengan symbol-simbol grafis yang menyatakan algoritma atau proses yang menampilkan langkah-langkah yang digambarkan menggunakan simbol tertentu, adapun diagram alir yang penulis rancang dapat dilihat pada Tabel 4.1.berikut ini:

Tabel 4.1. Flowchat Sistem Pendaftaran Pasien

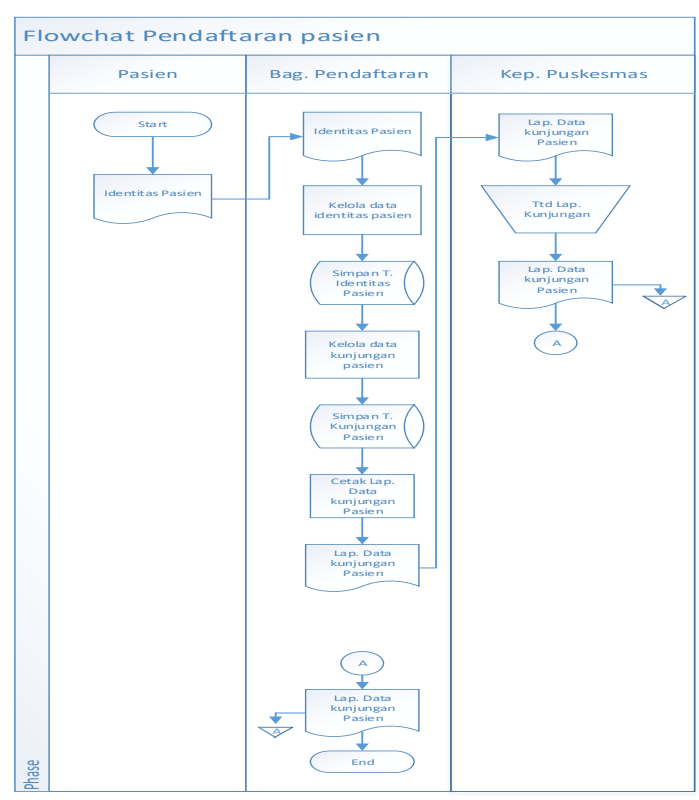

\section{Rancangan Sistem Basis Data}

Setelah merancang sistem yang baru, kemudian penulis merancang basis data untuk sistem yang akan diusulkan, yang dimana akan memudahkan dalam proses pembuatan basis data dan program yang akan dirancang.

\section{Tabel login}

Tabel ini berfungsi untuk masuk keprogram yang digunakan untuk masuk Sebagai Petugas. Berikut struktur tabelnnya:

Nama Tabel: dblogin

Field: 2

Keterangan: petugas

Tabel 4.2. Tabel login

\begin{tabular}{|c|c|c|c|}
\hline Nama field & Type & Size & Keterangan \\
\hline Id_admin & Int & 10 & $\mathrm{AI}$ \\
\hline Username & Varchar & 25 & $\begin{array}{lr}\text { Nama admin } & \text { yang } \\
\text { digunakan } & \text { untuk } \\
\text { login } & \end{array}$ \\
\hline Password & Varchar & 10 & $\begin{array}{lr}\text { Password } & \text { yang } \\
\text { digunakan } & \text { untuk } \\
\text { login } & \end{array}$ \\
\hline
\end{tabular}

\section{Tabel Pendaftaran Pasien}

Tabel ini berisikan data identitas pasien baru yang mendaftar berobat di puskesmas. Berikut struktur tabelnnya:

Nama Tabel: pendaftaran

Field: 8

Keterangan: data pendaftaran pasien baru. 
Vol. 01, No. 01, Maret 2021

Tabel 4.3. Pendaftaran Pasien

\begin{tabular}{|l|l|l|l|}
\hline Nama field & Type & Size & Keterangan \\
\hline id_pasien & Int & 10 & AI \\
\hline no_rm & Int & 10 & Nomor rekam medic \\
\hline nama_pasien & Varchar & 25 & Nama pasien \\
\hline nama_kk & Varchar & 25 & Nama kartu keluarga \\
\hline jenis_kelamin & Varchar & 15 & Jenis kelamin \\
\hline tgl_lahir & Int & 10 & Tanggal lahir Pasien \\
\hline Alamat & Varchar & 20 & Tempat tinggal pasien \\
\hline tgl_input & Date & & Tanggal Input data \\
\hline
\end{tabular}

\section{Tabel Kunjungan Pasien.}

Tabel ini berisikan tentang data kunjungan pasien. Berikut struktur tabelnnya:

Nama Tabel: dbkunjungan

Field: 8

Keterangan: data kunjungan pasien

Tabel 4.4. Kunjungan Pasien

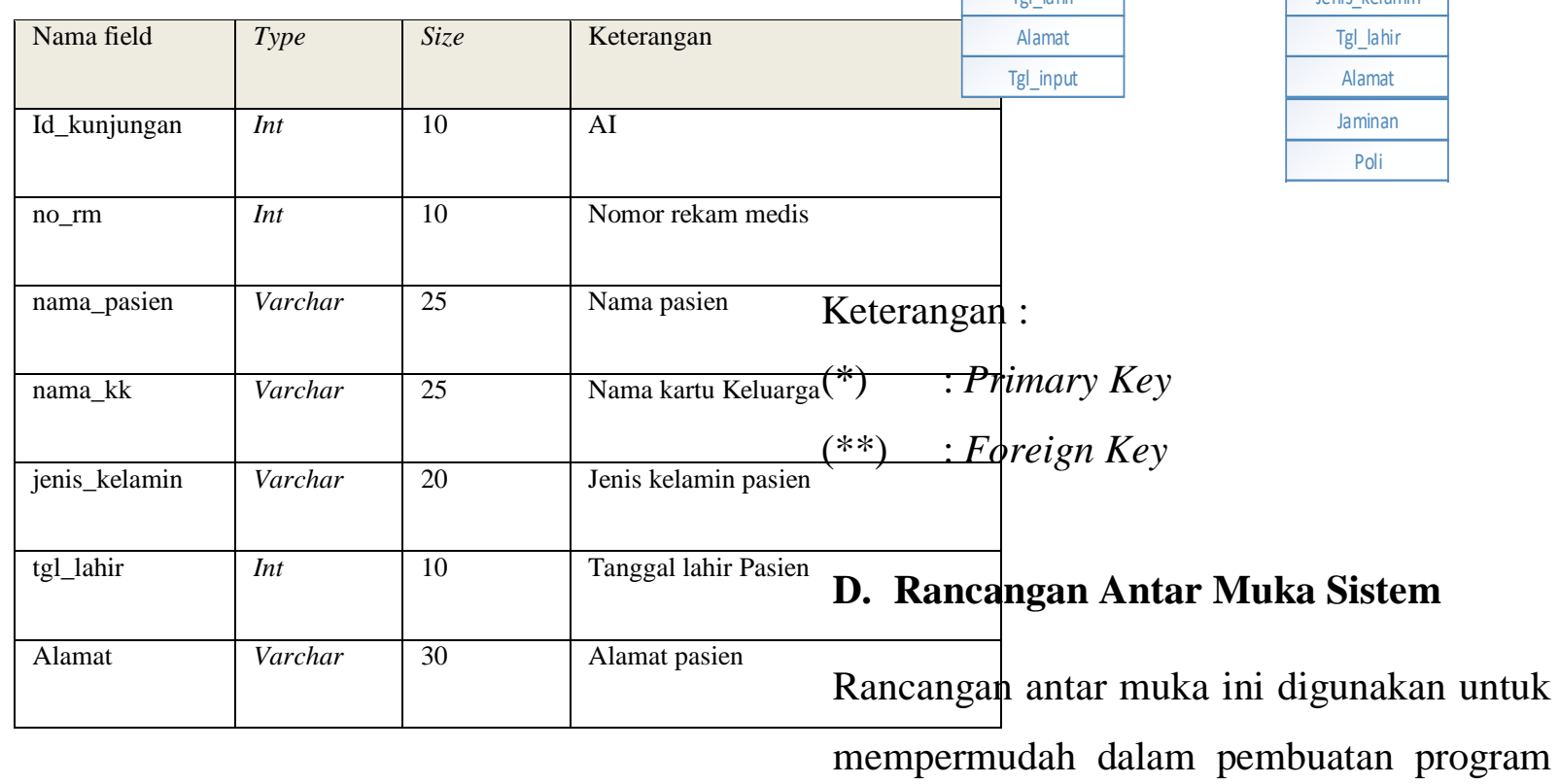

\begin{tabular}{|l|l|l|l|}
\hline Jaminan & Varchar & 15 & $\begin{array}{l}\text { Pembayaran menggunakan ASK } \\
\text { atau umum dll. }\end{array}$ \\
\hline Poli & Varchar & 15 & Poli tujuan \\
\hline tgl_kunjungan & Date & & Tanggal kunjungan pasien \\
& & & \\
\hline
\end{tabular}

\section{Normalisasi}

Normalisasi merupakan proses pengorganisasian file untuk menghilangkan grup elemen yang berulang menjadi tabel yang membentuk entitas dan relasinya. Adapun gambar normalisasi dapat dilihat pada gambar 4.4 berikut ini:

Tabel 4.5. Normalisasi tabel

\begin{tabular}{|c|c|}
\hline Pendaftaran & Kunjungan \\
\hline Id_Pasien* & Id_kunjungan* \\
\hline No_RM & Id_Pasien ** \\
\hline Nama_pasien & No_RM \\
\hline Nama_KK & Nama_Pasien \\
\hline Jenis_kelamin & Nama KK \\
\hline Tgl_lahir & Jenis_kelamin \\
\hline Alamat & Tgl_lahir \\
\hline \multirow[t]{3}{*}{ Tgl_input } & Alamat \\
\hline & Jaminan \\
\hline & Poli \\
\hline
\end{tabular}


Pendaftaran pasien, dan digunakan juga sebagai acuan untuk tampilan program yang akan dibangun.

\section{Rancangan Form Login}

Adapun rancangan form login ini berfungsi untuk mengakses atau masuk ke menu utama program, dengan memasukan username dan password yang sesuai, Gambar 4.4. berikut ini adalah rancangan form login:

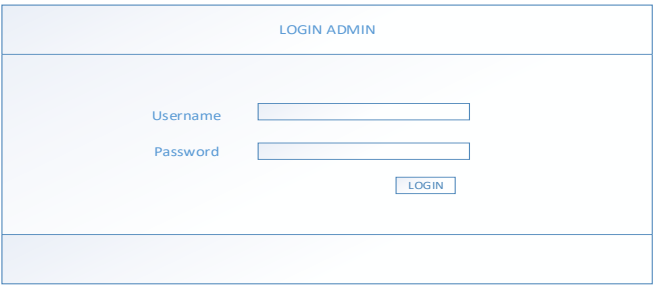

Gambar 4.4. Rancangan form login

\section{Rancangan Form Menu Utama}

Pada tampilan form menu utama adalah tampilan yang dirancang sebagai induk dari form yang akan dibuat didalam program ini, adapun rancangan form menu utama aplikasi pendaftara pasien dapat dilihat pada Gambar 4.5. berikut ini:

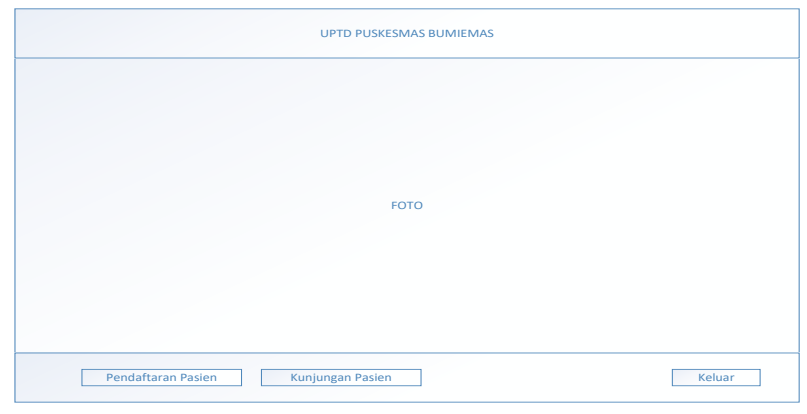

Gambar 4.5. Rancangan form menu utama

\section{Rancangan Form Pendaftaran} Pasien

Pada rancangan form Pendaftaran pasien berfungsi untuk menginput data pasien baru yang akan berobat di UPTD Puskesmas Bumiemas. Adapun rancangan form kunjungan pasien dapat dilihat pada Gambar 4.6. berikut ini :

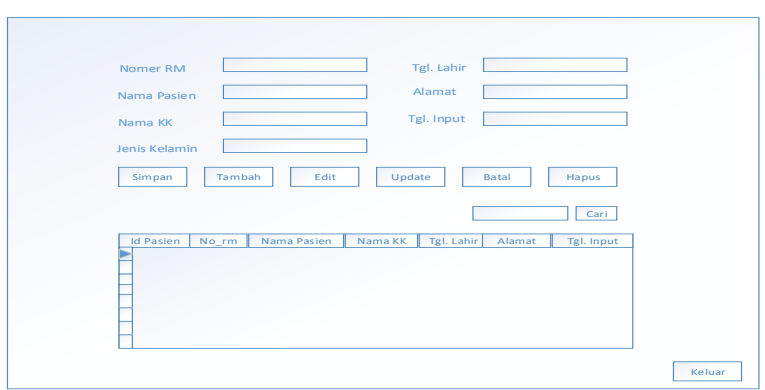

Gambar 4.6. Rancangan form pendaftaran pasien

4. Rancangan Form Kunjungan Pasien

Pada rancangan form kunjungan pasien berfungsi untuk memasukan data kunjungan pasien yang akan berobat kembali. Adapun rancangan form data kunjungan pasien dapat dilihat pada Gambar 4.7. berikut ini: 


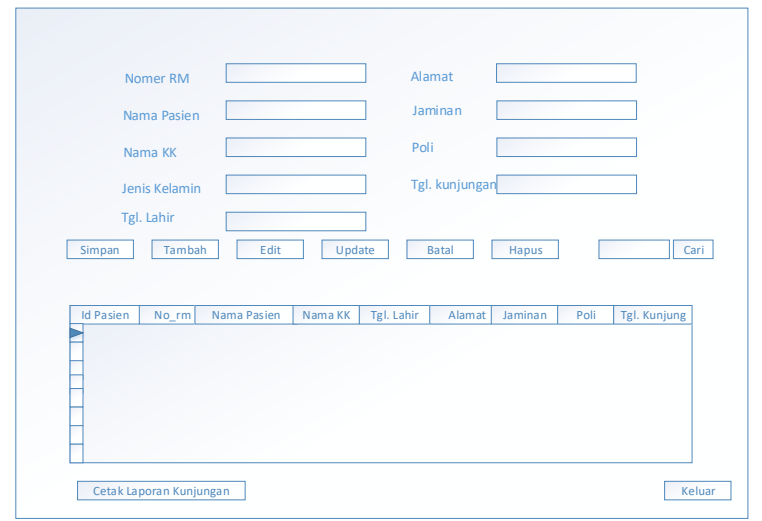

Gambar 4.7. Rancangan form kunjungan pasien

\section{Rancangan Form Cetak Laporan Kunjungan Pasien}

Perancangan form cetak laporan kunjungan digunakan untuk memfilter berdasarkan tanggal. Adapun rancangan form cetak laporan kunjungan pasien dapat dilihat pada Gambar 4.8. berikut ini:

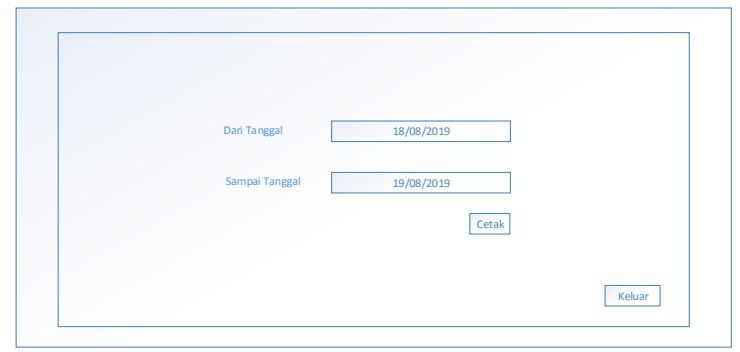

Gambar 4.8. Rancangan form cetak Laporan kunjungan

\section{Rancangan Output Laporan Kunjungan Pasien}

\begin{abstract}
Pada perancangan output laporan kunjungan pasien ini berisi tentang historis kunjungan pasien yang sudah berkunjung atau berobat pada puskesmas. Adapun rancangan output laporan kunjungan pasien dapat dilihat pada Gambar 4.9. berikut ini:
\end{abstract}

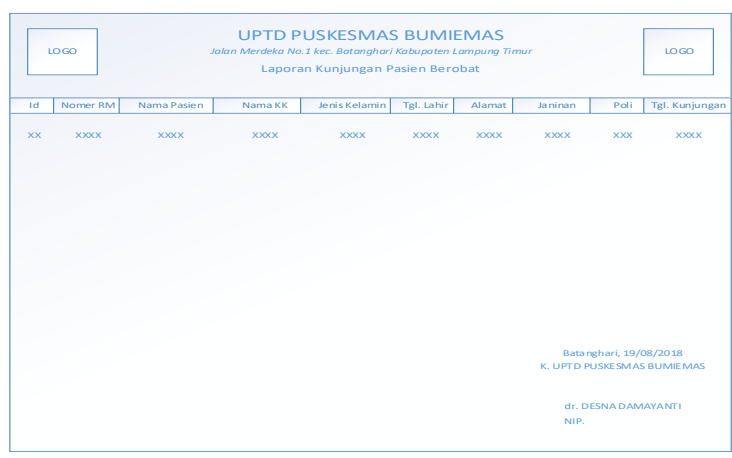

Gambar 4.9. Rancangan Output laporan data kunjungan pasien

\section{E. Pembahasan Program}

Pembahasan aplikasi bertujuan untuk memberikan intercae tentang desain program yang dibuat.

\section{Tampilan form login}

Pada tampilan login ini berfungsi untuk mengakses atau masuk ke menu utama program, dengan memasukan username dan password yang sesuai. Berikut ini adalah rancangan form menu login dapat 
dilihat pada Gambar 4.10. berikut ini:

LOGIN ADMIN

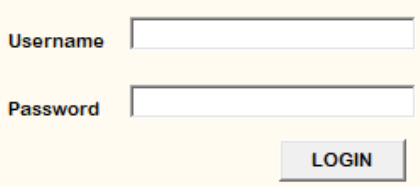

Gambar 4.10. Tampilan form login

\section{Tampilan Form Menu Utama}

Tampilan ini berfungsi sebagai tempat untuk menampilkan form pendaftaran pasien, kunjungan pasien, Berikut ini adalah rancangan form menu utama dapat dilihat pada Gambar 4.11. berikut ini:

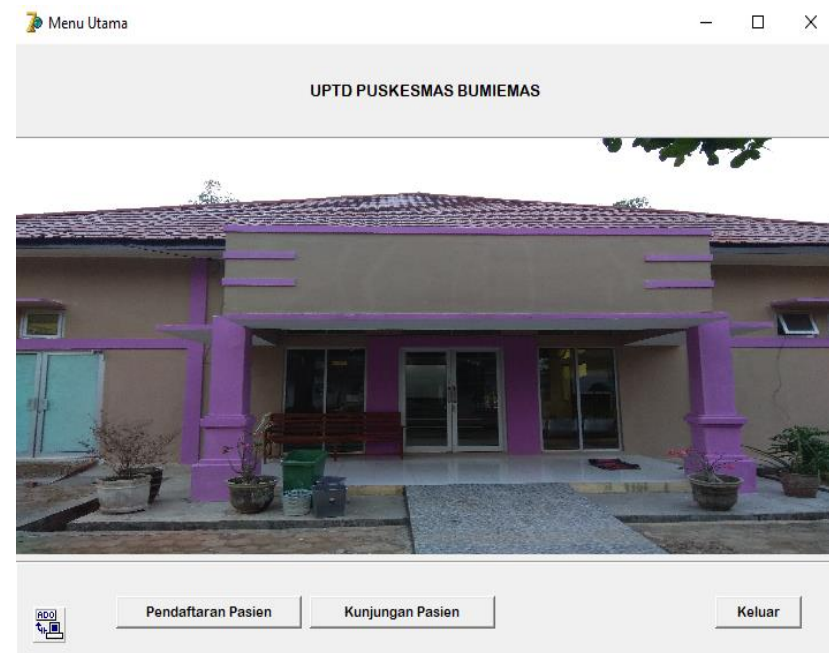

Gambar 4.11. Tampilan form menu utama

\section{Tampilan Form Pendaftaran} Pasien

Tampilan form pendaftaran pasien ini berfungsi untuk menginput data pasien baru yang mendaftar.Berikut ini adalah rancangan form pendaftaran pasien dapat dilihat pada Gambar 4.12. berikut ini:

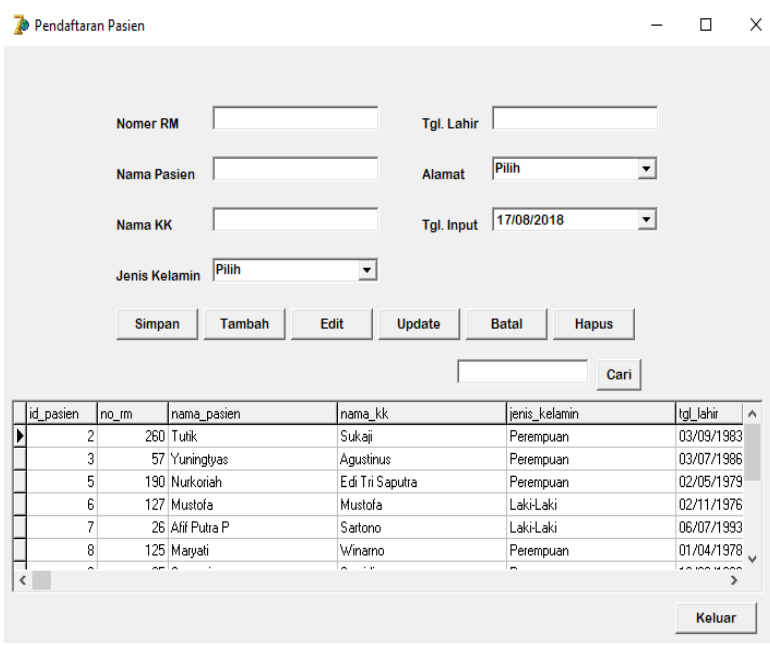

Gambar 4.12. Tampilan form pendaftaran pasien

\section{Tampilan Form Kunjungan Pasien}

Pada tampilan kunjungan pasien berfungsi untuk memasukan data pasien lama yang berobat kembali. Berikut ini adalah rancangan form kunjungan pasien dapat dilihat pada Gambar 4.13. berikut ini: 


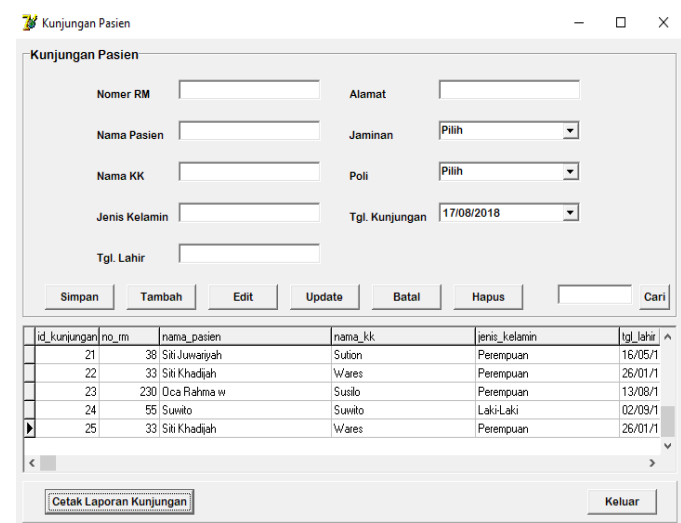

Gambar 4.13. Tampilan form kunjungan pasien

\section{Tampilan Form Cetak Laporan}

\section{Kunjungan Pasien}

Pada tampilan form cetak laporan kunjungan pasien ini berfungsi untuk mencetak laporan kunjungan pasien berdasarkan tanggal.Berikut ini adalah rancangan form cetak laporan kunjungan pasien dapat dilihat pada Gambar 4.14. berikut ini:

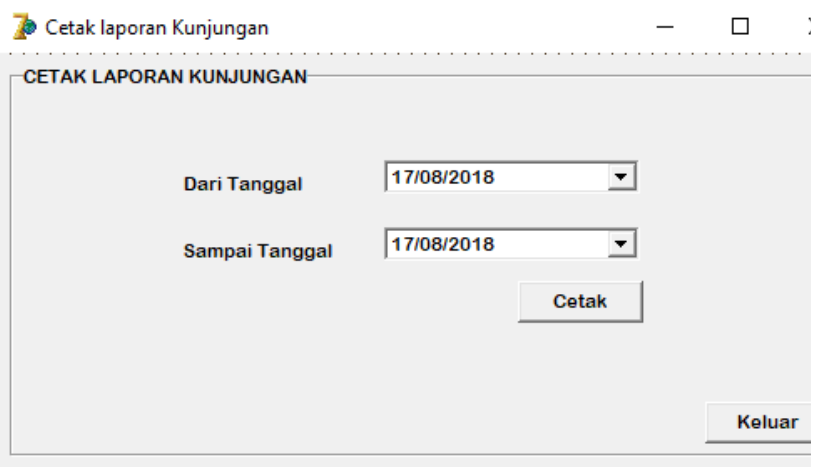

Gambar 4.14. Tampilan form cetak laporan kunjungan

\section{Tampilan Output Laporan Kunjungan Pasien}

Pada tampilan output kunjungan pasien ini berisi tentang historis kunjungan pasien yang sudah berkunjung atau berobat pada puskesmas. Berikut ini adalah tampilan output kunjungan pasiendapat dilihat pada Gambar 4.15. berikut ini:

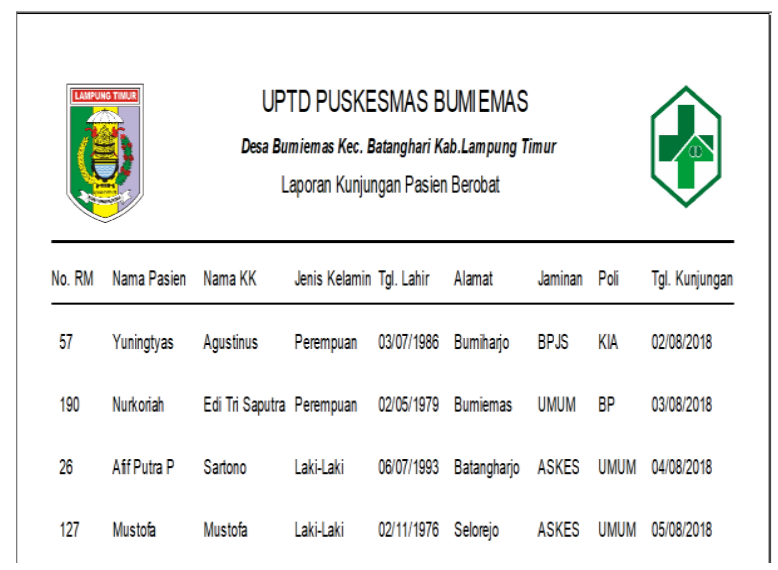

Gambar 4.15. Tampilan output laporan kunjungan pasien

\section{Kelebihan dan Kekurangan Program}

Adapun kelebihan dan kekurangan program yang telah dirancang adalah sebagai berikut:

1) Kelebihan Program 

Program yang dirancang penulis memiliki beberapa kelebihan yaitu:

a. Dengan menggunakan aplikasi pendaftaran pasien ini dapat mempercepat pencarian data.

b. Mempermudah pembuatan laporan kunjungan pasien.

c. Dapat menyimpan file dalam jumlah yang cukup besar.

2) Kekurangan Program

Program yang dirancang penulis memiliki beberapa kekurangan yaitu:

a. Program aplikasi pendaftaran pasien ini hanya dapat dibuka pada oprasi sistem berbasis windows.

b. Dalam aplikasi ini tidak ada pembuatan kartu register.

c. Tampilan dan warna pada program ini masih standar.

\section{KESIMPULAN}

Kesimpulan

Dari hasil penelitian pada UPTD Puskesmas Bumiemas dapat diambil kesimpulan yaitu:

- Aplikasi pendaftaran pasien ini dapat mempermudah petugas bagian pendaftaran dalam menginput data pendaftaran pasien baru yang berobat di UPTD Puskesmas Bumiemas.

- Dalam pembuatan aplikasi ini juga mempermudah pencarian data pasien ya berobat di UPTD Puskesmas Bumiemas.

- Aplikasi yang penulis buat ini juga mempermudah petugas dalam pembuatan laporan kunjungan pasien berobat lebih efektif dan efisien.

Saran

Meskipun aplikasi ini memiliki beberapa keuntungan dalam pengolahan data pendaftaran dan kunjungan pasien, namun masih memiliki banyak kekurangan yaitu:

- Aplikasi yang penulis buat ini masih sangatlah sederhana dalam tampilan program maupun warnanya masih setandar.

- Pada aplikasi ini diharapkan kedepannya ada perubahan dan pengembangan supaya aplikasi ini semakin baik dalam pengolahan data pendaftaran dan kunjungan pasien berobat.

\section{DAFTAR PUSTAKA}

[1] Agustin Reni. Sistem informasi Pelayanan Kesehatan Pasien Rawat Inap Pada Rumah Bersalin Xaverius 
Jurnal Mahasiswa llmu Komputer (JMIK)

Vol. 01, No. 01, Maret 2021

Tanjung Karang Bandar Lampung.

Jurnal Manajemen Sistem Informasi

Dan Teknologi.

[2] Apriana dan Saputra Danu Hernowo. 2009. Pembuatan Sofware Pencatat Pengunjung Perpustakaan Menggunakan Barcode dan MySQL Berbasis Boeland Delphi. 7.0. Volume 12 No.4. ISSN :1410-9662

[3] Maulana Halim. 2016. Analisis dan Perancangan Sistem Replikasi Database MYSQL dengan Menggunakan Vmware pada Sistem Oprasi Open Open Source. Jurnal Nasional Informatika dan Teknologi jaringan. Volume 1. No 1 ISSN : 2540-7600

[4] Prihantara Aditya dan Riasti Kusuma Berliana. 2012. Design Dan Implementasi Sistem Informasi Apotek Mitra Agung Pacitan. Jurnal Speed Sentra Penelitian Engineerig dan Edukasi - Volume 4 No. 3. ISSN : 1979-9330.

[5] Rudiyanto dan Jamaludin. 2016. Rancangan Bangun Program Aplikasi Penyimpanan Dokumen Berbasis
Desktop Studi Kasus Pada PT Mecosuprin Grafia Jakarta. Jurnal CKI On SPOT, Vol 9 No. 2. ISSN : 1979-7044

[6] Saputra Adi, Mulyadi, dan Martono. 2014. Perancangan Sistem Informasi Penerimaan Siswa Baru Berbasis Web Pada SMK N 6 Muaro Jambi. Jurnal Ilmiah Media SISFO, Vol. 8, No. 2. ISSN 1978-8126.

[7] Sanah Nor. 2017. Pelaksanaan Fungsi Puskesmas (Pusaat Pelayanan Masyarakat) Dala Meningkatkan Kualitas Pelayanan Kesehatan Di Kecamatan Long Kali Kabupaten Paser. eJurnal Ilmu Pemerintahan Vol. 5, No. 1. ISSN : 305-314.

[8] Susanto. 2014. Aplikasi Pendaftaran Dan Penerimaan Mahasiswa Baru Sekolah Tinggi Manajemen Dan Ilmu Komputer Musi Rawas (STIMIK MUARA) Berbasis Web. Jurnal TIPS, Vol.1, No. 1. ISSN 2470-2192.

[9] Susilowati Sinta dan Riasti Kusuma Berliana. 2011. Pembuatan Sistem Informasi Klinik Rawat Inap Prima Husada Widoro Pacitan Berbasis 
Jurnal Mahasiswa IImu Komputer (JMIK)

Vol. 01, No. 01, Maret 2021

Website. Jurnal Speed - Sentra

Penelitian Engineerig dan Edukasi -

Volume 3 No. 1. ISSN : 1979-9330.

[10] Susanto. 2015. Website Sistem Informasi Haji Pada Kantor Kementrian Agama Kota Lubujlinggau. JTI, Vol 7 No. 1.

[11] Yusmiarti Kusnita. 2016. Geogrsphic Information System (GIS) Sekolah Lanjut Tingkat Atas (SLTA) Pada Dinas Pendidikan Kota Agaralam. Volume 5 No.1. ISSN : 2301-5632 